\title{
Brazil: A For-Profit Giant
}

\author{
DANTE J. SALTO
}

Dante J. Salto is an advanced PhD student at the Department of Educational Administration and Policy Studies, and PROPHE Doctoral Research Associate, University at Albany, State University of New York. E-mail: dantesalto@gmail.com.

IHE regularly publishes articles from PROPHE, the Program for Research on Private Higher Education, headquartered at the University at Albany. See http:/ / www.albany.edu/ prophe.

Profit making in higher education engages controversial issues and debates involving the proper bounds of market activity. A discussion of the role of the for-profit sub-sector and its policy implications recently appeared in IHE (\#71, 2013). One key distinction identified there was between commercial, even forprofit and often shady activities in nonprofit institutions, and the growing reality of institutions that are for-profit by law. While it is widely recognized that many nonprofit institutions engage in profit making, this article deals with institutions that are legally allowed to distribute revenues among shareholders and specifically focuses on one of the world's largest higher education for-profit subsectors. Brazil's for-profits enroll over 2 million students (2010)—43 percent 
of the private sector and 32 percent of the overall system. Only by virtue of its own stunning growth early in the 21st century does the longstanding US forprofit subsector maintain a raw enrollment lead, with now over 3 million students; nevertheless, the for-profit share of the US higher education system is much smaller than its share of the Brazilian system-11 percent versus 32 percent, respectively.

The growth of the private sector and specifically the for-profit subsector in Brazil should be seen in perspective. With more than 6.5 million students (2010), Brazil has the largest higher education system in Latin America. However, by proportions of the age cohort enrolled (18-24 years old), Brazil lags behind most large Latin American countries, occupying the 11th place among all Latin American countries. Brazil has struggled to improve its enrollment profile. Today, Brazil lags only Chile in the private share of enrollment-73 percent and 79 percent, respectively; and for the last almost two decades Brazil has relied much more than any other Latin American country on the for-profit subsector.

By 2000, just a year after full-legal approval to allow for-profit higher education, the subsector already enrolled 18 percent of the private sector's and 12 percent of the system's students. Comparing the nonprofit and for-profit subsectors, striking is that for-profit boosted its size by 537 percent in the 20002010 period, displacing the public sector from its second position in enrollments, while the private nonprofit and the public sectors increased by only 88 percent and 85 percent, respectively. Large domestic and international companies with skyrocketing revenues have been key players in the growth of the for-profit subsector. 


\section{Public Policy}

Even if the spectacular for-profit growth had not been fully anticipated, it ensued from a formal public-policy decision. First, by a presidential decree signed in 1997, and then by a congressional amendment to the 1996 education law enacted in 1999, Brazil moved toward allowing for-profit higher education institutions on the recognition that many de jure nonprofit institutions were de facto for-profit, but the state was not collecting taxes. In other words, the massive private higher education expansion had led to nonprofits that were largely earning profits.

Some observers claimed that the regulatory changes during Fernando Cardoso's presidency in the 1990s had to do with the overall neoliberal policies promoted by his government in different sectors of the economy. Thus, with the election of the opposition, populist party in 2003, many observers doubted that the promotion of the private sector mainly its for-profit subsector, would continue. However, new President L. I. 'Lula' da Silva actually gave supportive public policy more vigor. His University for All Program to promote access to higher education specifically targeted the private sector-including the for-profit portion, through tax exemptions. The new government justified the necessity of this law and program on the grounds of persistent lagging and unequal access to higher education.

\section{Size AND SHAPE: FIELDS OF STUdY}

Consistent with major tendencies in private higher education globally, the forprofit subsector accumulates its largest share of enrollments in the fields of social science, business, and law (51\%), education (17\%), and health and social welfare $(15 \%)$. In contrast, the public sector shows a greater concentration in education 
(41\%), followed by social sciences, et al. (15\%), and engineering, production, and construction $(12 \%)$.

For-profits tend to offer programs with low costs and high rates of return to institutional investment. Following the same pattern as in enrollments, forprofit programs concentrate in social science, et al. (43\%), education (16\%), and health and social welfare (13\%). Unlike for enrollment, data on programs allow us to go a step further. Within the first group, most programs cluster in management and administration (22\%), law (5\%), accounting and taxation (5\%), and marketing and advertisement (4\%). Within education, pedagogy represents 6 percent, followed by teacher education in professional fields (3\%). Finally, within health and social welfare, most programs are found in therapy and rehabilitation $(4 \%)$ and nursing and primary care $(4 \%)$. The nonprofit subsector shows a similar composition in the share of fields and programs, in the same order as in the forprofit sub-sector. Contrasts are sharp to the public sector, which concentrates most of its programs in the field of education (41\%), followed by social sciences, business, and law (15\%), and engineering (12\%).

By whatever mix of planned and unplanned activity, Brazil has given the private sector overall, now very much including the for-profit subsector, a major role in access, keeping most selective institutions in the public sector. This reality, coupled with the fact that an overwhelming 95 percent of the for-profits are nonuniversity institutions, generate concern about quality in the for-profit subsector. Such concern is hardly unique to the Brazilian case and also is not limited to the legally for-profit portion of the private sector. Most mass private systems worldwide are characterized by private institutions that are on average decidedly inferior in quality to their public and elite private counterparts. On the 
other hand, Brazil's massive test (provão) of graduates found a range of quality in both private and public sectors, with for-profits out-performing what conventional wisdom expected.

Trends seem to point toward continuing growth of the for-profit subsector through two developments: 1) more nonprofit institutions switching their legal status; and 2) large domestic and international publicly traded companies incorporating nonprofit institutions to their business portfolios. All these trends show how increasingly diverse the Brazilian system is becoming. Although we know that for-profit prominence in this diversity exceeds, as seen in any other Latin American country, it will be interesting to discover what parallels already exist in the region and whether the Brazilian experience presages similar forprofit growth there. 